\title{
Naming Names in Human Genetic Variation Research
}

\author{
Morris W. Foster ${ }^{1,3}$ and William L. Freeman ${ }^{2}$ \\ ${ }^{1}$ Department of Anthropology, University of Oklahoma, Norman, Oklahoma 73019 USA, ${ }^{2}$ Indian Health Service Research \\ Program, Albuquerque, New Mexico 87110-1293 USA
}

\begin{abstract}
G enetic differences within and between populations may provide especially productive opportunities for using the sequence generated by the Human Genome Project (Committee on Human Genome Diversity 1997; Harding and Sajantila 1998). In particular, research into human genetic variation may hold long-sought answers to questions about common, complex diseases such as cancer, diabetes, and heart disease (McKeigue 1997; Shriver 1997). Whereas research into genetic variation is growing rapidly, existing human subjects' protections may not fully take into account population-specific risks.

Most threats come from lay persons rather than scientists. Naming a population in a scientific publication, though, can subject all members who share that social identity to risks (King 1992; Caplan 1994; Wolf 1995). Adverse association with disease predisposition can lead to discrimination and stigmatization (Andrews et al. 1994). The legal status of some populations may be jeopardized by genetic findings about their histories, for instance, affecting claims on land and prehistoric remains asserted by Native Americans (Grounds 1996). Findings that contradict how a community has used its traditional version of history to construct a unique identity may cause internal sociocultural harms, including psychosocial stress (Deloria 1995).

Population anonymity may eliminate many of these collective risks. If published scientific findings are not linked to a socially identifiable population, those results cannot endanger persons who share such identities. The scientific validity of studies of disease susceptibility and resistance would not be
\end{abstract}

\footnotetext{
${ }^{3}$ Corresponding author.

E-MAIL Morris.W.Foster-1@ou.edu; FAX (405) 325-7386.
}

significantly diminished by anonymity-just as pedigree studies have been unaffected by the use of anonymity. As in the case of anonymous pedigree studies, researchers can contact authors of population-anonymous studies for further information should there be reason to replicate findings, make additional comparisons, or investigate new questions. That exchange of information can be handled in a confidential manner that maintains respect for the population's authority to consent to new research proposals.

Although social identities have been used commonly in biomedical studies as surrogates for behavioral and environmental factors, they do not constitute the sole or even the most accurate sources of such information. Indeed, naming social identities (such as race) in biomedical publications may not be a scientifically valid means for linking biological, behavioral, and environmental contributors to health (LaVeist 1994; Williams 1997; Freeman 1998). The identities that have greater scientific validity for genetic studies may, in effect, be surrogates for large pedigrees_raising questions about naming populations, even under current ethical standards (Powers 1993; Botkin et al. 1998).

Anonymity is more problematic with respect to research into population history and the use of tissue collections. Unlike disease-specific research, naming social identities is intrinsic to population-history research, even when findings show that genetic populations, or demes, do not reflect recognized social boundaries. Although their findings are about the genetic structure of demes, studies of population history rely on social identities to orient and report their results (Cavalli-Sforza et al. 1994). At the same time, population histories answer primarily academic questions-about genetic studies of human evolution, lan- guage family relationships, prehistoric migration patterns, and isolation or admixture among others (von Haeseler et al. 1995; Stoneking 1997) - that offer few tangible benefits to members of populations investigated. Tissue collections that are open to researchers do not customarily distinguish among different kinds of genetic research nor have they typically offered population anonymity to donors nor required it of users (Clayton et al. 1995; Weir and Horton 1995).

An effort to create a worldwide tissue collection documenting genetic diversity, the Human Genome Diversity Project (HGDP), has foundered in part because of its proponents' insistence on naming donors' social identities and making their tissue samples available for a wide variety of research purposesincluding population-history studies (Cavalli-Sforza et al. 1991; Kidd et al. 1993). Indigenous peoples throughout the world objected to what they perceived as the colonialism of the HGDP, in which control over the scope of re search, patents, commercial royalties, and use of population names in publications all resided with researchers (Macilwain 1996). These concerns created a climate of suspicion about genetic research, particularly among Native Americans, that is an obstacle to studies using human variation to investigate disease susceptibility.

The cooperation of diverse populations is crucial for redeeming the considerable promises of the study of human genetic variation (Knoppers et al. 1996). However, many population-specific projects still do not consult with communities before recruiting members for genetic research. Standard informed consent agreements do not typically note the collective risks that published genetic findings may have for all persons who share a social identity. Research projects that necessarily publish 


\section{Insight/Outlook}

population names-such as genetic studies of population histories-typically do not weigh the ben efits and risks to those populations before doing so.

Recently, two initiatives have been announced by the National Institutes of Health (NIH) to create tissue collections that will reflect at least part of the worldwide human genetic variation (Collins et al. 1997; Brown and Hartwell 1998). In contrast to the HGDP, both initiatives have been sensitive to potential risks in revealing the social identities of specimen donors and are planning population-anonymous collections. Existing protection for human subjects for such collections, however, may not be adequate to reassure members of populations targeted for inclusion; lack of reassurance could lead, in turn, to refusal to participate. Not only could this result in the loss of important research opportunities, it also could makeadvances in ge netic medicine less available to minority populations.

The primary concern is that anonymity at the time of tissue donation may not guarantee anonymity in subsequent uses of those samples. This is because re searchers could use genetic analysis to determine the social identity of a donor-where there is some correspondence between social boundaries and genetic demes-and publish a population-specific study based on that identification (Shriver et al. 1997). This would be ethically questionable on two levels: (1) Such uses would contradict assurances of population anonymity given donors at the time of informed consent. Statements made about anonymity and the risks of population identification in informed-consent agreements are not necessarily reflected in tissue-collection user agreements. In fact, institutional review board evaluation of informedconsent agreements usually is not linked with evaluation of tissue-collection user agreements. Closer coordination between those two processes would ensure that representations made to participants are respected in subsequent uses of their specimens. (2) Such uses would circumvent community approval of research projects. Many communities that constitute relatively isolated populations, including Native American tribes, assert the right to subject research projects to communal approval. Researchers working with "reidentified" samples from initially population- anonymous collections could bypass that obstacle, particularly for research to which a population has significant objections. Although researchers may, for a time, be relatively free to pursue population-specific projects using population-anonymous collections, taking advantage of this ethical loophole ultimately could have a chilling effect on donations to tissue collections, as well as on consent for other kinds of research.

Advances in genetic sequencing and analysis will only simplify population identification of anonymous specimens. Thus, ethical constraints on subsequent uses of archival samples are an important protection. User agreements could specifically prohibit attempts to discover the social identity of any specimen. Funding agencies, institutional review boards, and scientific journals could treat such uses of populationanonymous samples as violations of 45 CFR 46-the federal rules that regulate human-subjects research-and refuse to support them, as well as sanction the offending researchers.

The NIH Resource, a populationanonymous tissue collection to be used for the identification of single nucleotide polymorphisms (SNPs), will have a user agreement that explicitly prohibits population identification. The inclusion of that prohibition in the user agreement was instrumental in obtaining $\mathrm{Na}$ tive American participation in the NIH Resource-overcoming widespread suspicions engendered by the HGDP about scientific investigations of genetic variation.

Researchers have a continuing obligation to donors of biological specimens, even when those specimens are obtained from archives. The conditions under which donations were made should be respected in determining ethical constraints on subsequent uses. Technological advances in genetic research should not be used to alter these obligations to donors or weaken protections for human subjects.

Anonymity, properly structured in both informed-consent and tissuecollection user agreements, can protect socially identifiable populations from most collective risks presented by genetic research. Violating the promise of anonymity would adversely affect a population's willingness to participate in future research. A loss of confidence in the research enterprise would limit the ability of scientists to investigate genetic variation as a tool to find treatments for diseases. Maintaining the promise of population anonymity, conversely, would both protect members of socially identifiable populations and help ensure the continued credibility of genetic research. Population anonymity also may resolve some of the ethical questions posed by existing tissue collections for which there is inadequate or overly broad informed consent for genetic research.

For vulnerable populations, anonymity should be the presumptive choice in the absence of compelling arguments for publishing a population's name or potentially identifying information. To compel publishing a name, scientific arguments should have sufficient ben efits for the population to outweigh the collective risks posed to its members. For example, some geneticists have asserted that population histories may be useful in elucidating polygenic disorders (Cavalli-Sforza 1998; Tyler-Smith et al. 1998). Although specific benefits of doing so have yet to be demonstrated, genetic investigation of population histories will fare better in a risk/benefit analysis when treated as a means for studying disease susceptibility, rather than as an end in itself. When considered as a means, though, population histories may be described without naming the population.

Genetic researchers who propose an association between a candidate haplotype and a disease try to build a convincing case, including taking account of possible arguments against such an association. The same care should be taken when naming a population in a published study. Researchers should not take that social identity as a given. Instead, they should consider arguments suggesting that naming populations may be ethically inappropriate or scientifically inaccurate. In making such choices, the first priority of research using human genetic variation should be ethical protections for participating populations.

\section{ACKNOWLEDGMENTS}

This work was supported in part by National Institutes of Health grant HG010302 and National Science Foundation grant SBR9610336 (both to M.W.F.). We thant Eric Meslin and Rich Sharp for their suggestions. The views 
expressed in this paper do not necessarily re flect the views of the Indian Health Service.

\section{REFERENCES}

Andrews, L.B., J.E. Fullarton, N.A. Holtzman, and A.G. Motulsky. 1994. Assessing genetic risk: Implications for health and social policy. National Academy Press, Washington, D.C.

Botkin, J.R., W.M. McMahon, K.R. Smith, and J.E. Nash. 1998. J. Am. Med. Assoc. 279: 18081812.

Brown, P.O. and L. Hartwell. 1998. Nat. Genet. 18: 91-93.

Caplan, A. 1994. In Justice and the Human Genome Project (ed. T. Murphy and M. Lappe), pp. 30-45. University of California Press, Berkeley, CA.

Cavalli-Sforza, L.L. 1998. Trends Genet. 14: $60-65$.

Cavalli-Sforza, L.L., A.C. Wilson, C.R. Cantor, R.M. Cook-Deegan, and M.C. King. 1991. Ge nomics 11: 490.

Cavalli-Sforza, L.L., P. Menozzi, and A. Piazza. 1994. The history and geography of human genes. Princeton University Press, Princeton, NJ.

Clayton, E., K.K. Steinberg, M.J. Khoury, E. Thomson, L. Andrews, M.J. Kahn, L.M. Kopelman, and J.O. Weiss. 1995. J. Am. Med. Assoc. 274: 1786-1792

Collins, F.S., M.S. Guyer, and A. Chakravarti. 1997. Science 278: 1580-1581.

Committee on Human Genome Diversity, National Research Council. 1997. Evaluating human genetic diversity. National Academy of Science, Washington, D.C.

Deloria, V. 1995. Red earth, white lies: Native Americans and the myth of scientific fact. Scribners, New York, NY. Freeman, H.P. 1998. Cancer 82: 219-225.

Grounds, R.A. 1996. Cult. Survival Q. 19: 6468.

Harding, R.M. and A. Sajantila. 1998. Nat. Genet. 18: 307-308.

Kidd, J.R., K.K. Kidd, and K.M. Weiss. 1993. Hum. Biol. 65: 1-6.

King, P.A. 1992. In Gene mapping: Using law and ethics as guides (ed. G.J. Annas and S. Elias), pp. 94-111. Oxford University Press, Oxford, UK.
Knoppers, B.M., M. Hirtle, and S. Lormeau. 1996. Genomics 34: 271-282.

LaVeist, T.A. 1994. Health Serv. Res. 29: 1-16.

Macilwain, C. 1996. Nature 383: 208.

McKeigue, P. 1997. Am. J. Hum. Genet. 60: 188-196.

Powers, M. 1993. IRB 15: 7-11.

Shriver, M.D. 1997. Ann. Intern. Med. 127: 401-403.

Shriver, M.D., M.W. Smith, L. Jin, A. Marcini, J.M. Akey, R. Deka, and F.E. Ferrell. 1997. Am. J. Hum. Genet. 60: 957-964.

Stoneking, M. 1997. Genome Res. 7: 87-91.

Tyler-Smith, C., A. Pandya, and F.R. Santos. 1998. Trends Genet. 14: 7-8.

von Haeseler, A., A. Sajantila, and S. Pääbo. 1995. Nat. Genet. 14: 135-140.

Weir, R, and J. Horton. 1995. IRB 17: 1-4

Williams, D.R. 1997. Ann. Epidemiol. 7: 322333.

Wolf, S. 1995. J. Law Med. Ethics 23: 345-353. 


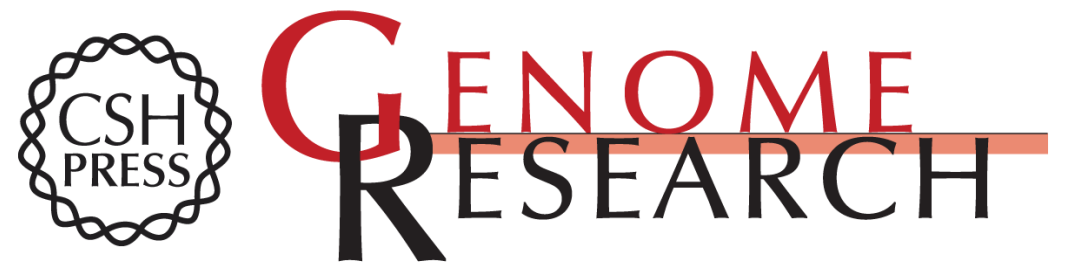

\section{Naming Names in Human Genetic Variation Research}

Morris W. Foster and William L. Freeman

Genome Res. 1998 8: 755-757

Access the most recent version at doi:10.1101/gr.8.8.755

References This article cites 19 articles, 2 of which can be accessed free at:

http://genome.cshlp.org/content/8/8/755.full.html\#ref-list-1

\section{License}

Email Alerting Receive free email alerts when new articles cite this article - sign up in the box at the Service top right corner of the article or click here.

\section{Affordable, Accurate Sequencing.}

To subscribe to Genome Research go to: https://genome.cshlp.org/subscriptions 